\title{
Evaluation of Seed Health Testing Methods for Alternaria sesami Causing Leaf Spot of Sesame
}

\author{
P.L. Radha* and S.N. Chattannavar
}

Department of Plant Pathology, Agricultural College, University of Agricultural Sciences,

Bijapur - 586 101, Dharwad, Karnataka, India

*Corresponding author

\section{A B S T R A C T}

Keywords

Sesame, Seed borne fungi, Seed health testing methods.

Article Info

Accepted:

21 September 2017

Available Online:

10 October 2017
Sesame is as an important oilseed crop and the diseases are taking heavy toll of the productivity. The seed borne organisms not only reduce the quality but also have an effect on germination. In view of these, understanding of seed borne mycoflora, their detection, and management are important. The present investigation on different seed health testing was undertaken during 20012-13 at Department of Plant Pathology, College of Agriculture, Bijapur, UAS, Dharwad. Among six different seed health testing methods used to assess their efficacy and reliability, standard blotter method was found to be good for the detection of seed borne infection of $A$. sesami in sesame.

\section{Introduction}

Sesamum or otherwise called as sesame, (Sesamum indicum L.) locally called as til, crop belongs to family Pedaliaceae, originated from East Africa. Sesame oil is known for its excellent nutritional, medicinal, cosmetic and cooking qualities for which it is considered as 'the queen of oils' in the West and in Tamil as 'nallennai' meaning good oil.

A large proportion of sesame is used for producing edible oil while purely white sesame seeds are in demand on conventional markets due to their high oil content. Sesamum oil is used for manufacturing perfumed oils and for medicinal purposes and the cake is a rich source of protein, carbohydrates and mineral nutrients such as calcium and phosphorous. It is also a valuable and nutritious feed for milch cattle.

Due to the presence of potent antioxidants (sesamolin and sesamol) which make the oil to be one of the most stable oils in the world. The seeds are called as 'the seeds of immortality'. Sesame is known as 'Queen of oil seeds" because seeds have high quality poly unsaturated stable fatty acids (PuFA). Moreover, seeds are rich source of edible oil (48-55\%) and protein (20-28\%) consisting both methionine and tryptophan, vitamin (niacine) and minerals (calcium and phosphorus) (Bedigian et al., 1985). 
According to Ayurveda the sesame seeds have aphrodisiac, demulcent, diuretic, emmenagogue, emollient, galactogogue, laxative, rejuvinative and tonic actions. It is useful for treating amenorrhea, burns, cholera, constipation, cough, dysentery, dysmenorrheal, gonorrhea, hemorrhoids, scalds, ulcers, wounds, etc.

In Karnataka and Maharashtra during Makar Sankranti festival, people exchange pieces of sugarcane, a mixer of fried til (sesame seeds), pieces of dry coconut, peanuts and fried gram or muticoloured tilguls made from til seeds and sugar and greet with the words 'ellu bell thindu, olle maathu aaduva' (Kannada - eat sesame seeds and speak only good); 'til-gul ghya, god god bola' (marathi- accept these tilguls and speak sweet words). This signifies the cultural attachment of people with sesame in India.

Sesame is the sixth important oil seed crop in the world with an area of $7.78 \mathrm{~m}$ ha and a total production of $3.15 \mathrm{~m} \mathrm{t}$ and an average yield of $405 \mathrm{~kg}$ per ha. Sesame is extensively cultivated in India, China, Myanmar, Sudan, Nigeria, Mexico, and to a small extent in Ethiopia, Uganda, Venezuela and Turkey (Anon., 2005).

In India, sesame occupies an area of about $183.45 \mathrm{~m}$ ha with a production of $7.70 \mathrm{~m} \mathrm{t}$ with a productivity of $303 \mathrm{~kg}$ per ha. Sesame is cultivated in marginal and submarginal areas as a rainfed crop throughout the country. Mainly grown in the states of Rajasthan, Gujarat, West Bengal, Madhya Pradesh, Maharashtra, Tamil Nadu, Andhra Pradesh, Karnataka, Uttar Pradesh and Orissa.

In Karnataka, sesame is grown over an area of 67 ha with a production of 31,000 tonnes with a productivity of $407 \mathrm{~kg}$ per ha. The acreage and production of sesame is declining in the traditional sesame growing areas due to several yield limiting factors like biotic and abiotic stresses (Anon., 2011).

Sesame is resistant to drought and tolerant to insect pests but it is susceptible to diseases like Alternaria and Cercospora leaf spots, powdery mildew and phyllody due to phytoplasma etc. Seed borne mycoflora are carried over by infected seeds and they cause deterioration in seed, in soil affecting germination, causing seedling mortality and further infection of foliage is observed at adult stage. Fungi including Alternaria, Curvularia, Fusarium, Helminthosporium, Pencillium, Mommoniella and Rhizophus sp. have been found associated with sesame seeds (ISTA, 1999).

Among these the Alternaria is the most destructive pathogen of sesame; as it produces small brown spots on leaf ranging from 1-8 $\mathrm{mm}$ in diameter. It reduces the viability of seeds and the seed borne pathogens are the most disastrous as they reduce the seed vigour and weaken the plant at the initial of its growth. In view of the seed borne pathogens, causing substantial damage by them and to study the different aspects of the fungal pathogens and their effects on seed the following objectives were formulated.

\section{Materials and Methods}

The present investigations were carried out in the plant pathology laboratory of College of Agriculture, Bijapur of University of Agricultural sciences, Dharwad during 201213. The details of materials used and the methodology followed in conducting the experiments are presented here under.

Borosil and corning glasswares were used for all the laboratory experimental studies. They were kept for a day in the cleaning solution containing $60 \mathrm{~g}$ potassium dichromate, $60 \mathrm{ml}$ of concentrated sulphuric acid, in one liter of 
water. Then they were cleaned by washing with detergent solution followed by rinsing several times in tap water and finally with distilled water. All glassware used in the studies were sterilized in autoclave at 1.1 $\mathrm{kg} / \mathrm{cm}$ pressure for $20 \mathrm{~min}$ and kept in hot air oven at $60^{\circ} \mathrm{C}$ for one hour. Both solid and liquid media were sterilized at $1.1 \mathrm{~kg} / \mathrm{cm}$ pressure for $15 \mathrm{~min}$.

\section{Evaluation of seed health testing methods}

To know the efficacy of different seed health testing methods in detecting seed borne fungi of sesame, following methods were employed as described below.

\section{Standard blotter method}

The standard blotter method was developed by Doyer in 1938 which was later included in the International Seed Testing Association Rules of 1966. Four hundred seed of each variety were tested by employing standard blotter method in three replications. Three pieces of blotting paper of $90 \mathrm{~mm}$ size were moistened with distilled water and placed in $90 \mathrm{~mm}$ sterilized Petri plates after draining excess water. Untreated seeds were placed at the rate of 20 seeds per Petri plate at equal distance. The plates were incubated at room temperature $\left(25 \pm 2^{\circ} \mathrm{C}\right)$ under alternate cycles of 12 hrs NUV light and darkness.

After eight day of incubation the seeds were examined under stereoscopic-binocular microscope for the associated fungi and they were identified based on "morphological and colony characters (Anon., 1996).

\section{Deep freezing blotter method}

Four hundred seeds of sesame variety E -8 were placed at the rate of 20 seeds per plate on moistened blotter in the way as described under standard blotter method. The Petri plates were incubated at $25 \pm 2{ }^{\circ} \mathrm{C}$ for $24 \mathrm{hrs}$ under alternate cycles of $24 \mathrm{hrs}$ NUV light and darkness, for next 24 hrs the plates were incubated at $-20^{\circ} \mathrm{C}$ in dark and then kept back under original condition for the next six days. After eight days of incubation the seeds were examined under stereoscopic-binocular microscope.

\section{2, 4-D Blotter method}

Four hundred seeds of sesame variety E -8 were placed at the rate of 20 seeds per Petri plates with moistened blotters dipped in $0.2 \%$ solution of sodium salt of 2, 4 dichlorophenoxy acetic acid. The Petri plates were incubated in the way as described under standard blotter method. After eight days of incubation the fungal growth on seeds was examined using stereoscopic-binocular microscope (Khare, 1996).

\section{Water agar method}

Four hundred seeds of sesame variety E -8 were placed at the rate of 20 seeds per Petri plate containing $20 \mathrm{ml}$ of 2 per cent water agar. The Petri plates were incubated for seven days as described under standard blotter method. After seven days of incubation the fungal growth on seed was examined under stereoscopic-binocular microscope.

\section{Agar plate method with potato dextrose agar}

Four hundred seeds of sesame variety E-8 were surface sterilized with 1 per cent sodium hypochlorite solution for 1-2 min and then placed at the rate of 20 seeds per Petri plate containing $20 \mathrm{ml}$ of potato dextrose agar. The Petri plates were incubated for seven days as described under standard blotter method. After seven days of incubation the fungal growth on seeds was examined under stereoscopic binocular microscope. 


\section{Paper towel method (rolled towel method)}

This method is used to know the effect of seed-borne inoculum on seed quality parameters of sesame i.e., to carry out germination and vigour tests of apparently healthy and infected seed lots of sesame and also to see the effect of different seed treatments on seed-borne inoculum as per the International Seed Testing Association Rules (Anon., 1996).

Randomly selected 100 seeds were placed on two layers of moist germination paper, which were placed on a polythene paper and rolled carefully to avoid any excess pressure on seeds. These towels were incubated in seed germinator at $25 \pm 2^{\circ} \mathrm{C}$ for six days.

All the morphologically normal seedlings were counted and germination was expressed in percentage. To find out the seedling vigour, ten normal seedlings were taken from the germination test at random and the root length was measured from the collar region to the tip of the primary root and the mean root length was expressed in $\mathrm{cm}$. The same seedlings were used for the measurement of shoot length. The shoot length was measured from the collar region to the point of junction of cotyledons. The mean shoot length was expressed in centimeters. Vigour index was calculated by the following formula, given by Abdul Baki and Anderson (1973).

Vigour Index $=$ Seed germination (\%) $\times$ Seedling length (Shoot + Root length $(\mathrm{cm})$ ).

\section{Results and Discussion}

A number of standard methods for seed health testing are used to test seeds for the presence of seed-borne fungi. The standard blotter method (SBM) and deep freezing blotter method (DFB) are recommended by the ISTA (1996). It is known that with SBM, saprophytes develop quickly and often impair the detection of parasitic fungi, while with DFB, the growth of saprophytic bacteria and yeasts is enhanced, which may inhibit spore germination of some of important seed-borne fungi (Neergaard, 1979). With these methods, it is difficult to detect some seed-borne pathogens due to their slow growth rates. Further, several criteria are involved in selecting a suitable procedure for the detection of different fungi in seeds. The primary criterion being its capacity to reveal the fungi in maximum percentage, another is its versatality and capacity to reveal a wide range of pathogens. Keeping these two points in view, a study was conducted to compare the six routine seed health testing methods for detection of different fungi in seeds.

Table.1 Evaluation of different seed health testing methods in detecting the seed- borne infection of A. sesami in sesame

\begin{tabular}{|c|l|c|}
\hline SI.N0. & \multicolumn{1}{|c|}{ Method } & Percent Seed infection \\
\hline 1. & Potato Dextrose Agar method & $68.25(55.75)^{*}$ \\
\hline 2. & Deep freezing blotter method & $12.22(20.11)$ \\
\hline 3. & 2,4- D blotter method & $19.70(26.26)$ \\
\hline 4. & Water Agar method & $12.15(20.30)$ \\
\hline 5. & Standard blotter method & $91.63(73.32)$ \\
\hline 6. & Paper towel method & $23.82(29.19)$ \\
\hline & SEm \pm & 1.51 \\
\cline { 2 - 3 } & CD at $1 \%$ & 6.16 \\
\hline
\end{tabular}

* Arcsine transformed values 


\section{Plate.1 Evaluation of different seed health testing method}

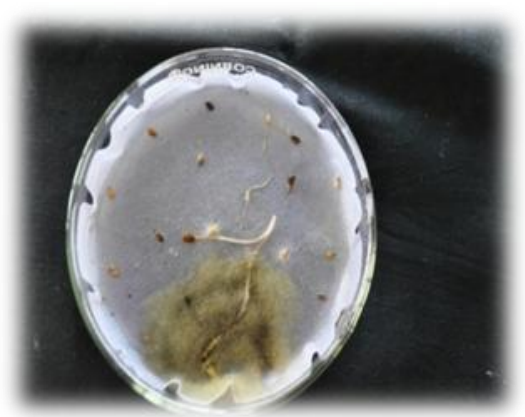

1. Standard blotter method

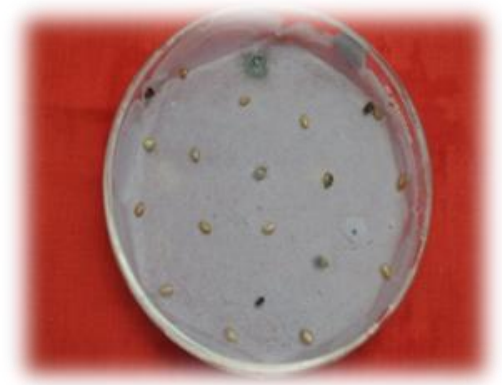

4. Deep freezing standard blotter method

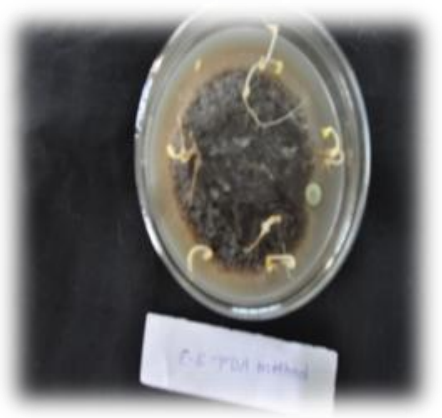

2. Potato dextrose agar method

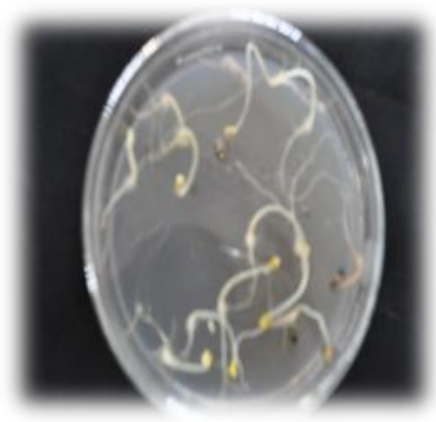

3. Water agar method

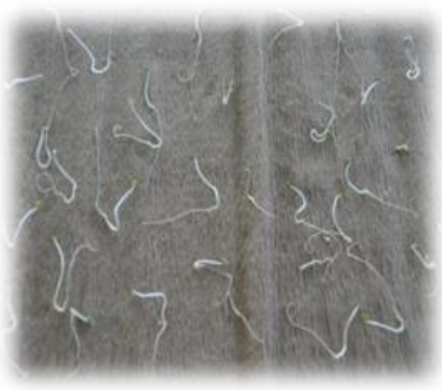

5. Paper rowel method

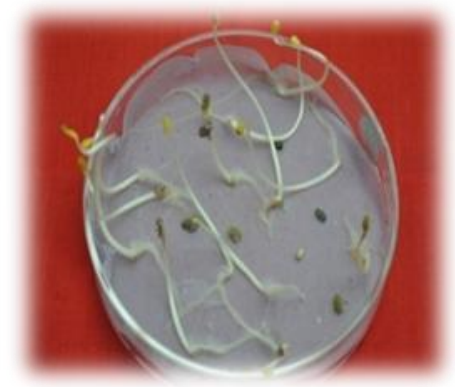

6. 2, 4 - D blotter method
Among these six different methods used, standard blotter method was found to be good for the detection of Alternaria sp and was found statisticaly significant and superior over other methods (Table 1, Fig.1 and Plate.1), higher counts of Alternaria sesami were recorded in this method $(91.63 \%)$ followed by potato dextrose agar method $(68.23 \%)$. Water agar method was found to be least effective for the detection of $A$. sesami as it recorded least seed infection of 12.15 per cent.

The finding of the present study are in concurrence with several methods have been developed to detect the seed borne mycoflora and the emphasis has been given to those methods which were simple, economic, sensitive, reproducible and efficient (Neergard, 1977).

The findings of the present study were in concurrence with earlier findings of Ahmed (1982) Bhale et al., (2000) and Kumudkumar et al., (2004). Hence, it can be concluded from the present study that Standard blotter method can be recommended for routine seed health diagnosis of $C$. capsici as the method is simple, sensitive and reproducible.

Hence, it can be concluded from the present study that standard blotter method can be recommended for routine seed health diagnosis of seed borne fungal infection in sesame as the method is simple, sensitive and reproducible.

\section{References}

Abdul Baki, A.A., and Anderson J P. 1973. Vigour determination in soybean seeds by multiple criteria. Crop Sci. 13: 630633.

Ahmed, S.S., 1982. Studies on seed borne aspects of anthracnose of chillies caused by Colletotrichum capsici (Sydow.) Butler and Bisby. M.Sc. (Agri.) Thesis, 
Univ. Agric. Sci., Bangalore. 87. Anonymous, 2005 FAO Statistical Year Book, Publishers Food and Agriculture Organization of UN. Rome. 75-76.

Anonymous, 2011. Ministry of Agriculture Government of India www.agricrop.nic. in p-1-197.

Bedigian, D., Seiogler, D S and Harlan J R, 1985. Sesamia, sesamolia and the origin of sesame. Biochem. Syst. Ecology. 13: 133-149.

Bhale, U., Bhale M S, Pandey B. R. and Pandey R P. 2000. Seed borne fungi of chilli in Madhya Pradesh and their significance. J. Mycopath. Res. 38(2): 117-119.ISTA (International Seed Testing Association) 1996. International rules for seed testing rules. Seed Sc. Tech. 24: 1-335.

Doyer, L.C., 1938, Manual for the determination of seed-borne diseases. Wageningen, Netherlans: International Seed Testing Assoc., p. 59.

ISTA (International Seed Testing Association), 1999. International Rules for Seed Health Testing. Seed Sci. Tech. 24: 1-335.

Kumudkumar Singh, J., and Khare A. 2004. Detection, location transmission and management of seed borne Colletotrichum dematium causing dieback and anthracnose in chilli. Farm Sci. J. 13(2): 152-153.

Neergaard, P., 1977 Seed Path, Vol I and II. Mc Millan Press, London, UK. 1187.

Neergaard, P., 1979. Danish species of Alternaria and Stemphylium, Hamphry Millfor. Oxford University Press, London. 566.

\section{How to cite this article:}

Radha, P.L. and Chattannavar, S.N. 2017. Evaluation of Seed Health Testing Methods for Alternaria sesami Causing Leaf Spot of Sesame. Int.J.Curr.Microbiol.App.Sci. 6(10): 24052410. doi: https://doi.org/10.20546/ijcmas.2017.610.283 